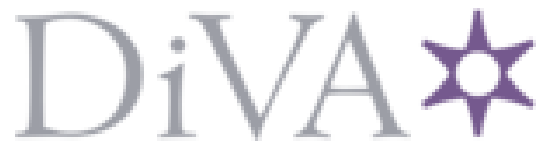

http://www.diva-portal.org

This is the published version of a paper published in Scandinavian Journal of Public Health.

Citation for the original published paper (version of record):

Frieberg, O-P., Millqvist, E., Nilsson, J., From, I. (2018)

Development and validation of the self-administered Falun health instrument (SAFHI)

using data from health promoted workplaces in Sweden

Scandinavian Journal of Public Health, 46(7): 735-743

https://doi.org/10.1177/1403494817728668

Access to the published version may require subscription.

N.B. When citing this work, cite the original published paper.

Permanent link to this version:

http://urn.kb.se/resolve?urn=urn:nbn:se:du-26424 


\title{
Development and validation of the self-administered Falun health instrument (SAFHI) using data from health promoted workplaces in Sweden
}

\author{
OTTO-PATRIK FRIEBERG ${ }^{1}$, EVA MILLQVIST ${ }^{2}$, JAN NILSSON $^{3,4} \&$ INGRID FROM $^{5}$
}

${ }^{1}$ Health Centre Läkarhuset Unicare, Borlänge, Sweden; Centre of Clinical Research (CKF), Dalarna, Sweden, ${ }^{2}$ Department of Internal Medicine/Respiratory Medicine and Allergology, University of Gothenburg, Sweden, ${ }^{3}$ Department of Medical Science, Sophiahemmet University, Sweden, ${ }^{4}$ Department of Health Sciences, Karlstad University, Sweden, and

${ }^{5}$ The School of Education, Health and Social Studies, Dalarna University, Sweden

\begin{abstract}
Aim: The aim of this study was to develop and to validate the self-administered Falun health instrument. An additional aim was to test its applicability in measuring people's lifestyles linked to health. Methods: In 2002, an instrument was constructed containing questions regarding the hazardous use of alcohol, tobacco, unhealthy diets and insufficient physical activity. A pilot study using the instrument was assessed between 2002 and 2006. In Sweden, it was further expanded and tested during the years 2004-2014 among a total of 1295 people. Results: Face validity was evaluated among colleagues and experts for clarity and completeness resulting in minor adjustments of some questions. With the test-retest method, the selfadministered Falun health questionnaire showed a positive and high reproducibility and high compliance. Cronbach's alpha showed a high level of consistency (average 0.86). Factor analysis demonstrated the choice of questions correlated highly to the measured lifestyle. Conclusions: This study showed that the self-administered Falun health questionnaire is a valid and reliable instrument, useful for detecting individuals at risk of developing diseases that are related to individual choice of lifestyle.
\end{abstract}

Key Words: Health behaviour, Health education, Health interventions, Instrument development, Life style, Public Health, Selfreported health

\section{Introduction}

In 1997, the Swedish government commissioned the Swedish Council on Technology Assessment in Health Care (SBU) [1] to review all ongoing and completed intervention studies relating to public health work in Sweden. In accordance with this, the SBU assessed the large Swedish population-based interventions but criticized them for lacking scientific rigour and for having weaknesses in the evaluation. In a systematic review from 1997, the SBU [1] recommended the development of methods in populationbased prevention programmes. The purpose of this report was to assess population-based programmes in the US in 1972, 1980, 1981 and 1982, Finland in 1972, Switzerland in 1977, Germany in 1984 and Ireland in 1984. All of these studies were populationbased interventions. The studies showed the conventional risk factors for developing diseases, but also studied the intermediate indicators as lifestyle factors. Conventional risk factors are smoking, dyslipidemia, and hypertension. The indicators are based on an individual's lifestyle and health behaviour. These experiences resulted in national guidelines for disease

Correspondence: Otto-Patrik Frieberg, Health Centre Läkarhuset Unicare in Borlänge, Gyllehemsvägen 1078460 Borlänge, Sweden. E-mail: patrik. frieberg@1tdalarna.se

Date received 1 October 2016; reviewed 19 fuly 2017; accepted 24 fuly 2017

(C) Author(s) 2017

Article reuse guidelines: sagepub.com/journals-permissions

DOI: $10.1177 / 1403494817728668$

journals.sagepub.com/home/sjp 
prevention methods [2]. The guidelines focus on use of tobacco, use of alcohol, lack of regular physical activity and unhealthy diets, all being the lifestyle factors that mostly contribute to the overall burden of diseases in Sweden [2]. The core of the prevention methods is counselling, which can be given on three different levels depending on the patient's needs: advising, primary prevention and qualified counselling [2]. Additional components can be the prescription of drugs and/or regular physical activity [3, 4].

A government bill from the Department of Health in Sweden in 2002 [5] prompted the development of methods to measure health indicators related to people's living habits. The intention was to create social conditions in order to reduce disparities in health between different groups in the population regardless of class, gender and ethnicity. The bill pointed out a lack of methodological development in relation to the measurement of public health. The main message of this bill was that there were only a few intervention projects and these lacked scientific structure and reproducibility. The development of validated instruments to measure health and individuals' lifestyles and to monitor population health trends [6] were encouraged. The results from large populationbased public health reports in Sweden were based on mathematical calculations and described as not entirely truthful, since there was a lack of scientific level [7].

Collecting data through self-reported screening instruments has become popular around the world. Several published articles, using screening instruments, showed that a variety of negative health behaviours are correlated to morbidity and mortality [8]. A large population-based prevention programme in Finnish Karelia showed the possibility to influence people's lifestyles related to alcohol use and unhealthy diets by cardio-vascular disease interventions, resulting in increased survival [9]. In Australia 2012 Dal Grande et al. [10] investigated people's health through a selfreported health questionnaire including items about alcohol use, smoking, nutrition and physical activity. Similarly, in North America between 2005 and 2008, Zajacova et al. [11] studied physical and psychological health conditions with a self-reported health questionnaire. In Sweden, the ULF study [12] has followed and studied people's living conditions since 1975. Individual indicators that are collected in the study include for example general health, environmental health, economic conditions, social relations and education [13].

Researchers within the Swedish healthcare system had already realized by the 1970 s the need to find new solutions to address public health problems in the community [14]. According to the National Board of Health and Welfare [2], public health goals should promote a good working environment, encourage increased physical exercise, sound diets, reduced harmful use of alcohol, a drug-free society, a more health-oriented healthcare, coordinated public health, long-term commitment to research and method development.

In Sweden, the National Board of Health and Welfare describes lifestyle factors that can affect health such as stress and affliction, social support and networks, the work situation, confidence, the ability to be in control of your life, hope and optimism [4]. Health promotion programmes using screening instruments such as self-reported questionnaires have been implemented over the last decade though the evaluation has been inadequate [15]. The practice of such programmes varies within the population depending on the target group being investigated, such as migrants, students or industrial workers $[16,17]$. Health-preventive information is not only needed for employees, but for all groups of inhabitants in society [18]. Weinehall et al. $[9,19]$ at Umeå University assessed a public health project for the prevention of cardio-vascular problems in the northern region of Sweden. Results of the interventions, which included information on diets and exercise, led to healthier diets, including food-labelling products $[9,19]$. Food-labelling is an element of the intervention. Guidelines for prevention are available only to a limited extent [20]. However, such guidelines must be easy to understand, practical to use, not too time-consuming, and evidence-based.

A number of screening instruments are validated measuring health [21-26] and lifestyle [22, 23, 2731]. However, descriptions of instruments that measure an individual's basic lifestyle related to the intake of essential nutrients, use of alcohol, tobacco, and regular physical activity, are lacking.

Several people have many ongoing unhealthy lifestyle habits, indicating that the risk is not only additive but also multiplicative. It is of special concern that people with additional unhealthy lifestyle habits receive help and support to change their lifestyle habits [2]. Therefore in this study, parameters describing inactivity, smoking, alcohol consumption, and food intake were chosen and studied.

The aim of this study was to develop and to validate the self-administered Falun health instrument (SAFHI). An additional aim was to test its applicability in measuring people's lifestyles linked to health. 


\section{Materials and methods}

Construction of the self-administered Falun

health instrument (SAFHI)

The SAFHI was constructed to measure the recommended features that can influence lifestyle, in accordance with Becker [32,33] and Sox [34] who described the question areas in more detail. These areas match the fields of health prevention in the Oxford Handbook of Public Health Practice [8], and recommendations about diet intake (RDI) $[32,33]$ and recommended daily physical activity (RDF) [34-36]. The SAFHI comprises questions regarding the hazardous use of alcohol, hazardous tobacco use, unhealthy diets and insufficient physical activity. The questions were created during a master's degree in medical sciences. In a pilot project 2002-2006, the purpose was to measure differences in lifestyle habits in two different companies using the SAFHI. The results showed positive differences in health development. A registered nurse, a medical engineer and a clinical physiologist all with special competence in health promotion finally reviewed the questionnaire to be a part of this study. The registered nurse had many years of professional experience in diet planning and counselling for patients in public health. The medical engineer had many years of knowledge from creating databases for recording different variables and being able to fold them. The clinical physiologist was also trained in nutrition and had many years of experience in clinical practice.

A questionnaire needs to build on the strength of evidence about the health measures recommended $[8,34]$. The 14 questions are divided into five categories. Category one includes question numbers 1-7 and asks about food intake based on evidence from earlier studies [32-34, 37-40]. Category two includes question numbers $8-11$ asking about regularity of food intake $[35,37,41,42]$. Category three includes question number 12 asking about use of alcohol [22, 34, 35, 37]. The issue of alcohol consumption in the SAFHI questionnaire is based on the estimated normal consumption according to Bergman et al. [43]. Category four includes question number 13 and asks about use of tobacco [34, $35,37]$. Finally, category five includes question number 14 asking about regular exercise per week [34-37]. Each question is built on evidence about causes of illness according to the recommendations from the National Food Agency in Sweden [32, 33, 37]. RDI and RDF strictly define the metabolic system with regard to the lack of or too high a consumption of fat, vitamins, minerals, alcohol, nicotine, and lack of regular exercise, and the causes are correlated to the risk of developing illness. Response alternatives and scores are described in Table I. The total score for the questionnaire was 100 points (pts). A higher score reflects a better lifestyle. The questionnaire was translated from Swedish to English for this article by a translater.

\section{Study population}

Between 2004 and 2014 the instrument was further expanded and administered to a population of 1295 individuals. Through advertisements in the local press, small companies with 10-50 employees in three different counties in mid-Sweden were invited to participate in the study and, at the same time, were offered physical examination for their employees. A total number of 12 companies to participate in the study, resulting in 1295 participants. The mean age of the participants was 46 years (range 20-66), $48 \%$ were women and 52\% were men. In 2012 the SAFHI was tested in a study of the employees $(n=40)$ in two companies, in two counties. They answered the questionnaire on two occasions during the same period of time with eight weeks in between. The reason for the eight-week interval between test-date one and two was so that the individuals would not remember the wording of the questions or have changed their lifestyles.

The companies were chosen with the purpose of representing two dissimilar workplaces [44]. Company 1 represented an official company of economic advisors where the employees had a minimum of three years of education in secondary school and some of them had a higher education at college or university level. Company 2 represented different professions in healthcare. Those with the lowest education in both companies had a three-year education in secondary school and those with higher education had a university or college degree in the field of health and medical science. The respondents from company 1 had 20 employees, $52 \%$ male and $48 \%$ female, and company 2 had 20 employees, $80 \%$ women and $20 \%$ men. All the employees in both companies agreed to participate and were scheduled for a first and second visit to complete the SAFHI. The first author conducted all interviews. At that point, all participants were informed that their employer would not be party to the interview process the individual responses. Furthermore, the interviewer did not evaluate the respondents' answers and it was in the respondents' own interest to answer as truthfully as possible.

\section{Data processing}

Data analyses were undertaken using Statistical Package for Social Sciences (SPSS) programme at 
Table I.

\begin{tabular}{|c|c|c|c|}
\hline Items in English & Items in Swedish & Options for item response & References \\
\hline $\begin{array}{l}\text { I regularly eat green vegetables } \\
\text { such as spinach, green peppers, } \\
\text { dill, parsley, broccoli, green peas } \\
\mathrm{X} \text { number of times out of } 14 \\
\text { possible meals per week. }\end{array}$ & $\begin{array}{l}\text { Jag äter regelbundet gröna grönsaker } \\
\text { som exempelvis spenat, grön paprika, } \\
\text { dill, persilja, broccoli, gröna ärter X } \\
\text { antal gånger av } 14 \text { möjliga måltider per } \\
\text { vecka. }\end{array}$ & $\begin{array}{l}3-4 \text { times }=2 \mathrm{pts} \\
5-7 \text { times }=5 \mathrm{pts} \\
7-8 \text { times }=10 \mathrm{pts}\end{array}$ & {$[31-33,36]$} \\
\hline $\begin{array}{l}\text { 2. How many days a week do you } \\
\text { eat fruit? }\end{array}$ & Hur många dagar i veckan äter du frukt? & $\begin{array}{l}3-4 \text { times }=1 \mathrm{pt} \\
5-6 \text { times }=3 \mathrm{pts} \\
7 \text { times }=5 \mathrm{pts}\end{array}$ & {$[31-33,36]$} \\
\hline $\begin{array}{l}\text { 3. I drink milk, fil, yoghurt } \mathrm{X} \\
\text { number of decilter/day. }\end{array}$ & $\begin{array}{l}\text { Jag dricker mjölk, fil, yoghurt X antal dl/ } \\
\text { dag. }\end{array}$ & $\begin{array}{l}0-2 \mathrm{dl}=0 \mathrm{pts} \\
2-5 \mathrm{dl}=4 \mathrm{pts} \\
>5 \mathrm{dl}=2 \mathrm{pts}\end{array}$ & {$[36,37]$} \\
\hline $\begin{array}{l}\text { 4. I drink X number of litres of } \\
\text { water per day. }\end{array}$ & Jag dricker $\mathrm{X}$ antal 1 vatten /dag. & $\begin{array}{l}<1 \text { litre }=0 \mathrm{pt} \\
1-1.5 \text { litre }=2 \mathrm{pts} \\
>1.5 \text { litre }=4 \mathrm{pts}\end{array}$ & {$[36,38]$} \\
\hline $\begin{array}{l}\text { 5. I eat fish X number of times/ } \\
\text { week. }\end{array}$ & Jag äter fisk X antal ggr/vecka. & $\begin{array}{l}1 \text { time } / \mathrm{w}=1 \mathrm{pt} \\
2 \text { times } / \mathrm{w}=3 \mathrm{pts} \\
3 \text { times } / \mathrm{w}=5 \mathrm{pts}\end{array}$ & {$[34,36]$} \\
\hline $\begin{array}{l}\text { 6. As a rule, I use vegetable or } \\
\text { animal fats in the household. }\end{array}$ & $\begin{array}{l}\text { Jag använder som regel vegetabiliska eller } \\
\text { animaliska fetter i hushållet. }\end{array}$ & $\begin{array}{l}\text { No }=7 \mathrm{pts} \\
\text { Yes }=10 \mathrm{pts}\end{array}$ & {$[34,36,39]$} \\
\hline $\begin{array}{l}\text { 7. I normally eat white or dark } \\
\text { bread. }\end{array}$ & Jag äter som regel vitt eller mörkt bröd. & $\begin{array}{l}\text { White bread }=0 \mathrm{pts} \\
\text { Dark bread }=2 \mathrm{pts}\end{array}$ & {$[36,40]$} \\
\hline 8. I eat breakfast every day. & Jag äter frukost varje dag. & $\begin{array}{l}0 \text { days }=0 \text { pts } \\
5 \text { days }=5 \text { pts }\end{array}$ & {$[34,36,41,42]$} \\
\hline 9. I eat lunch every day. & Jag äter lunch varje dag. & $\begin{array}{l}0 \text { days }=0 \text { pts } \\
5 \text { days }=5 \text { pts }\end{array}$ & {$[34,36,41,42]$} \\
\hline 10. I eat supper every day. & Jag äter kvällsmat varje dag. & $\begin{array}{l}0 \text { days }=0 \text { pts } \\
5 \text { days }=5 \text { pts }\end{array}$ & {$[34,36,41,42]$} \\
\hline $\begin{array}{l}\text { 11. I eat snacks between meals } \\
\text { every day. }\end{array}$ & Jag äter mellanmål varje dag, $\mathrm{fm}+\mathrm{em}$. & $\begin{array}{l}\text { No }=0 \mathrm{pts} \\
\text { Yes }=5 \mathrm{pts}\end{array}$ & {$[34,36,41,42]$} \\
\hline $\begin{array}{l}\text { 12. Over a two-week period, I drink } \\
\text { a maximum of } 1 \text { litre of wine, } \\
12 \mathrm{cl} \text { of liquor and } 2 \text { litres of beer. }\end{array}$ & $\begin{array}{l}\text { Jag dricker någon sorts alkohol under två } \\
\text { veckor, maximalt } 4 \text { glas vin/2 glas sprit/2 } \\
\text { liter starköl. }\end{array}$ & $\begin{array}{l}\text { Wine }=-5 \text { pts } \\
\text { Liquor }=-10 \text { pts } \\
\text { Beer }=-3 \text { pts }\end{array}$ & {$[21,33,34,35]$} \\
\hline 13. I use tobacco or snuff regularly. & Jag nyttjar tobak eller snus regelbundet. & $\begin{array}{l}\text { Smoking }=-40 \mathrm{pts} \\
\text { Snuff }=-5 \mathrm{pts}\end{array}$ & {$[33,34]$} \\
\hline $\begin{array}{l}\text { 14. I regularly exercise a number of } \\
\text { hours per week. }\end{array}$ & $\begin{array}{l}\text { Jag motionerar regelbundet antal timmar } \\
\text { per vecka. }\end{array}$ & $\begin{array}{l}1 \mathrm{hr}=10 \mathrm{pts} \\
2 \mathrm{hrs}=20 \mathrm{pts} \\
3 \mathrm{hrs}=30 \mathrm{pts} \\
4 \mathrm{hrs}>=40 \mathrm{pts}\end{array}$ & {$[33-36]$} \\
\hline
\end{tabular}

pts: health index points.

the institute centre for clinical research at the county council of Dalarna (CFK). Programme effect was determined by examining the differences in answers among the questionnaire respondents [20]. Compared $t$-test between subjects, multiple analysis of variance (Manova) to evaluate changes in the several scales on wellbeing were made. Validity and reliability were analysed with test-retest reliability using Pearson's coefficient. The Cronbach's alpha method was used to analyse the internal consistency.

\section{Ethical considerations}

Permission for the study was given by the board of managers in the included companies. The ethical review was approved by the ethics committee at Uppsala University (Dnr 20031125). After oral and written information about the study, the respondents gave their informed consent in writing. Information was given about confidentiality and privacy laws, and ethical considerations were discussed. All information related to a patient's privacy is protected by law from other interests. To protect the patients' rights the respondents were informed that they could, at any time, immediately revoke their participation, performance and actions without explanation.

\section{Results}

Face validity

Colleagues and experts at the clinic, informally reviewing its clarity and completeness, evaluated the face validity of the SAFHI during the construction of 


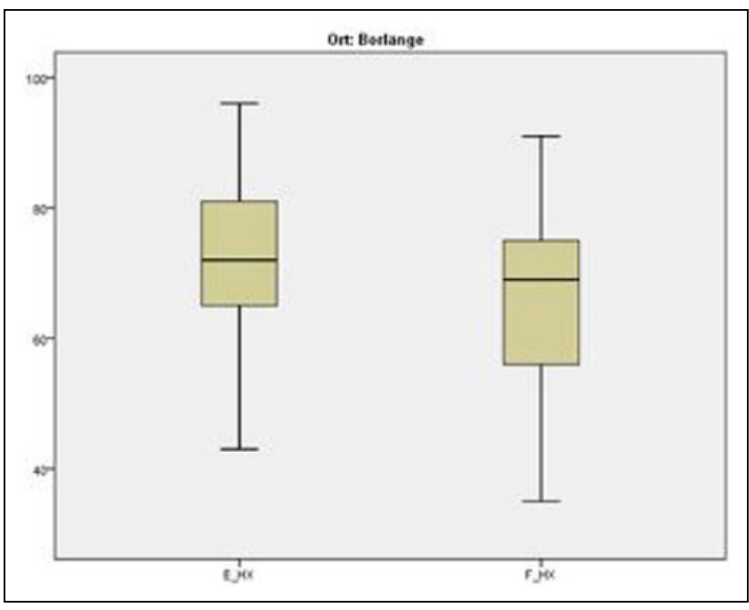

Figure 1. Company 1. First answering opportunity and second answering opportunity. Respondents' health index results, range: $43-96$ pts.

the questionnaire. Minor adjustments of some questions were made to improve respondents' comprehension of the questionnaire (Table I).

\section{Range}

A box plot presentation of the SAFHI score results at two opportunities in company 1 and company 2 show that the range is centred. The top and bottom of the box represent the $25^{\text {th }}$ and $75^{\text {th }}$ percentiles, the horizontal line is the median. See Figures 1 and 2 .

\section{Degree of consistency}

The degree of consistency between assessments one and two appeared to have a good correlation and high significance. The average health index points for company 1 in the first measurement were $70.5 \mathrm{pts}$, and in the second 66.0 pts. In company 1 the health index in the first measurement was $48.0 \mathrm{pts}$, and in the second 52.0 pts.

\section{Interclass correlation coefficient}

The Cronbach's alpha results for 44 persons in single measures were 0.75 and average measures 0.86 . The correlation coefficients are high in both participant companies.

\section{SAFHI frequency distributions}

At company 1 in Borlänge, 21 persons of 21 (100\%) answered the SAFHI on two occasions; the mean age was 53 years. At the first answering opportunity, in January 2006, the mean score was 66.67 . and at the

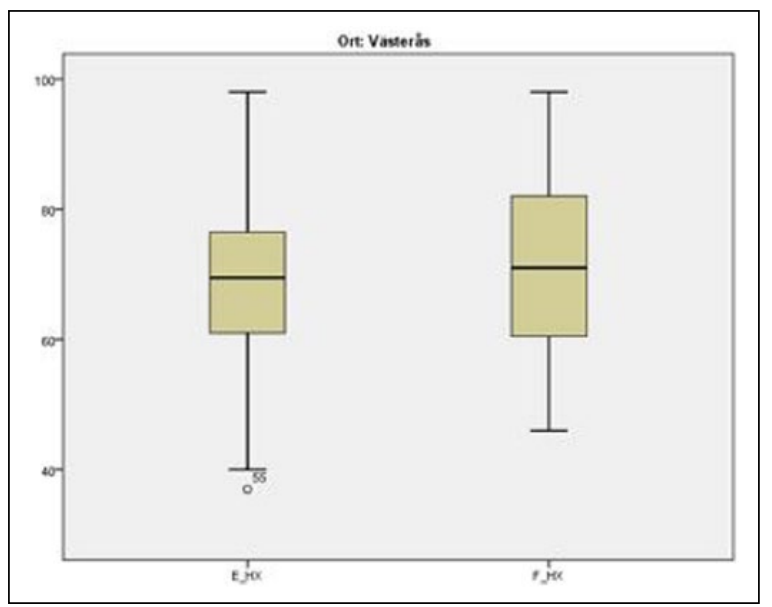

Figure 2. Company 2. First answering opportunity and second answering opportunity. Respondents' health index results, range: $37-98$ pts.

second opportunity in March it was 70.52 pts, range 43-96 pts (Table II).

At company 2, in Västerås, 23 persons of 23 $(100 \%)$ answered the SAFHI on two occasions, mean age 45 years. At the first answering opportunity, in January 2006, the mean score was 70.52, and at the second opportunity in March, 66.04 pts, range 37-98 pts (Table III).

To confirm significance in an inter-item correlation 0 indicates no correlation, and 1 the maximum of correlation. In the choice of questions by correlation analysis the following results were found in the inter-item correlation between items (I) and they were distributed as follows: I14 to $1=0.71 ; \mathrm{I} 7$ to $1=$ $0.67 ; \mathrm{I} 1$ to $1=0.63 ; \mathrm{I} 5$ to $1=0.50 ; \mathrm{I} 2$ to $1=0.39 ; \mathrm{I} 6$ to $1=0.32$; I13 to $1=0.20$; Items $3,4,8,9,10,11$, 12 to $1=0.15$. The value of the inter-item correlation matrix in test 1 was 0.77 , and in test 2 was 0.77 , providing support for a high correlation [45]. The single measure for interclass correlation coefficient was 0.75 and the average measure was 0.86 , also showing a high correlation.

The results show that there is a high correlation between items asking about regularity of physical exercise and food intake such as vegetables and health. Questions about intake of products high in fat like oil and omega III-rich fish such as salmon are important. Use of tobacco has a strong correlation with health, while questions about dietary products, water intake, and regularity in food intake have less importance.

\section{Discussion}

The results from this pilot study showed that the SAFHI generated approximately normal distributions and showed good test-retest reliability 
and satisfactory internal consistency. In the present investigation, with the help of a number of lifestyle questions weighting health, the objective was to find out whether the SAFHI score correlated to people's lifestyles and living habits.

Screening methods using self-reported questionnaires can reveal people who are predisposed to develop diseases and for them self-care should be recurrent in education at all levels. Development of instruments to measure people's adherence to health and illness have always been historically interesting. The main issue is whether the right questions are asked [46]. The report from the SBU in 1997 [15] showed that none of the 34 different intervention projects produced any significant results. They were inadequate and could not be reproduced and described scientifically. Only one of these 34 projects was accepted and published as a scientific paper $[9,19]$. Between 1997 and 2010 the National Board of Health and Welfare in Sweden published the new national

Table II. Descriptive statistics for the SAFHI in Company 1.

\begin{tabular}{lcc}
\hline & Test 1 & Test 2 \\
\hline Mean (95\% CI) & $(59.97-73.36)$ & $(64.50-76.55)$ \\
5\% trimmed mean & 66.63 & 70.70 \\
Median & 70.0 & 71.00 \\
Variance & 216.433 & 175.162 \\
Std. deviation & 14.712 & 13.235 \\
minimum & 43 & 43 \\
maximum & 91 & 95 \\
Range & 48 & 52 \\
Interquartile range & 26 & 18 \\
Skewness & -0.068 & -0.198 \\
Kurtosis & -1.008 & -0.230 \\
\hline
\end{tabular}

guidelines regarding public health promotion focusing on the use of alcohol and tobacco, food intake and regularity of physical exercise [8]. There is still a lack of useful instruments to address these issues.

The three focal points in the development of a questionnaire are that it should be easy to measure, easy to undertake and available. Several instruments fulfilling these criteria have been developed. Nordin et al. [21] describe the development of a questionnaire regarding chemical sensitivity, which is based on an earlier questionnaire on noise sensitivity. In the Chemical Sensitivity Scale (CSS) 11 of 21 items were selected and shown to be easy and appropriate to use for the epidemiological study and clinical diagnosis of sensory hyper reactivity used with other tools in diagnostic work [21]. The Quality from the Patients' Perspective instrument (QPP) was developed stepwise from a questionnaire comprising many questions, by reducing the number of items to the main core issues [47]. This instrument showed a high validity and proved to be an easy instrument to use. Another instrument showing high validity and reliability was developed by Sørensen et al. [48] who created the Danish EQ-5D, which is a generic instrument for measuring health-related quality of life in population health surveys, and Glasberg et al. [49] designed an instrument to measure the stress of conscience. Nilsson et al. [50] constructed a questionnaire on nurses' self-reported skills, the NPC Scale. Common for all of these instruments was that they initially had many questions that were condensed to fewer core items giving the same results, which is also similar to the development of the SAFHI.

The uniqueness of the SAFHI, is the ability to measure lifestyle factors in individuals and similarly on a group level, which is also recommended by the SBU [51] and the National Board of Health and

Table III. Descriptive statistics for the SAFHI in Company 2.

\begin{tabular}{lcc}
\hline & Test 1 & Test 2 \\
\hline Mean (95\% CI) & $70.52(64.5-76.6)$ & $66.04(59.8-72.3)$ \\
$5 \%$ trimmed mean & 70.36 & 65.93 \\
Median & 70.00 & 64.00 \\
Variance & 196.806 & 208.862 \\
Std. deviation & 14.029 & 14.452 \\
minimum & 46 & 37 \\
maximum & 98 & 98 \\
Range & 52 & 61 \\
Interquartile range & 19 & 15 \\
Skewness & 0.169 & -0.085 \\
Kurtosis & -0.482 & 0.382 \\
\hline
\end{tabular}


Welfare [2]. The joint development of such instruments should be based on the use of the Cronbach's alpha method in the statistical processing, as was used in this instrument.

In this survey the Cronbach's alpha value was 0.86 , indicating high validity. Factorial analysis of the issues has been an important guide in this investigation. Similar questions have been defined by national guidelines for disease prevention methods [2]. This study focused on the test-retest of the questionnaire. Moreover, it was tested in small and large groups, in various professional groups, and also in several geographical areas, with the intention to present the results in future articles.

Common deficits in intervention projects are a lack of case report formularies, shortages in the statistical analysis and the deficiency of theoretical evidence in the process of development in a scientific procedure [51]. One weakness in the SAFHI was the question about the use of alcohol and tobacco. In this investigation no whole blood analyses were assessed to indicate, for example, the use of alcohol, which could have been a way to verify whether the answers were reported truthfully. Though the SAFHI is meant to be self-administrated, personal interviews were chosen to strengthen trust between the interviewer and the respondent, and the intention was to get better and truer answers but also to minimize falling-off. Yet there may have been an interviewer effect [52] influencing the responses, both in positive and negative ways, such as issues relating to alcohol or regularity of exercise. In this study, the questionnaire responses resulted in an evident pattern regarding the correlation analysis between the values of the questions. Other studies of alcohol use in clinical practice [53] showed that questions about alcohol use can facilitate preventive clinical work. In the preventive dialogue the truth of the answers are of lesser importance than the patient getting awareness about the risk of use.

Other important factors are whether the respondent understands the meaning of the question, and whether the respondent's mood when completing a questionnaire can affect the responses positively or negatively [52]. However, the interviews did not reveal any objections or questions regarding interpretation of the issues. In summary, this study presents a new instrument to measure health factors for both individuals and groups. It should be emphasized that the sample of participants from two companies cannot be considered to be representative of the general population but it serves well for the present purpose of a metric evaluation of the SAFHI. Thus further research should be conducted to obtain normative data.
Today there is a focus on the prevention of various diseases to save human lives and suffering [54]. Working with disease prevention in parallel with treating non-lifestyle-related disease could result in significant savings [13].

\section{Acknowledgements}

The authors would like to acknowledge Professor emeritus Urban Rosenqvist at the Department of Internal Medicine (General Medicine), Public Health, Uppsala University for initiating the project and supervision. Thanks also to the statistician Jan Ifver for valuable supervision and the statistical analysis. Special thanks goes to the Centre of Clinical Research (CKF) in the county of Dalarna for supporting the data analysis.

\section{Declaration of conflicting interests}

The author(s) declared no potential conflicts of interest with respect to the research, authorship, and/or publication of this article.

\section{Funding}

The author(s) received no financial support for the research, authorship, and/or publication of this article.

\section{References}

[1] The Swedish Council on Technology Assessment in Health Care [Statens beredning för medicinsk utvärdering (SBU)]. Disease prevention in the heart and vessels through population-based programmes: A systematic literature review [Att förebygga sjukdom i hjärta och kärl genom befokningsinriktade program: en systematisk litteraturöversikt]. Report no. 134, 1997. Stockholm: SBU.

[2] The National Board of Health and Welfare [Socialstyrelsen]. Nationella riktlinjer för sjukdomsförebyggande metoder 2011 [National guidelines for disease prevention 2011], http://www.socialstyrelsen.se/Lists/Artikelkatalog/Attachments/18484/2011-11-11.pdf (accessed 8 September 2017).

[3] The Swedish Society for Physical Activity [Yrkesföreningen för fysisk aktivitet (YFA)]. FYSS Fysisk aktivitet i sjukdomsprevention och sjukdomsbehandling [Physical activity in the prevention and treatment of disease], 2008, http://fyss. se/wp-content/uploads/2011/02/FYSS-2008-hela-boken. pdf (accessed 8 September 2017).

[4] The Swedish Council on Technology Assessment in Health Care [Statens beredning för medicinsk utvärdering (SBU)] Metoder att främja fysisk aktivitet. En systematisk litteraturöversikt [Methods for promoting physical activity. A systematic literature review]. Report no. 181, 2007 Stockholm: SBU, http://www.sbu.se/contentassets/c2cb6581355047b48367 f19e1c9e3700/fysisk aktivitet.pdf (accessed 8 September 2017).

[5] Swedish Government. Public health goals [Mål för folkhälsan]. Regeringens proposition 2002;03:35.

[6] The Swedish Council on Technology Assessment in Health Care [Statens beredning för medicinsk utvärdering (SBU)]. Utvärdering av metoder $i$ hälso- och sjukvården [Evaluation of methods in health care systems]. Falköping: Erlanders Sverige $\mathrm{AB}, 2013$. 
[7] Public Health Agency of Sweden. [Folkhälsomyndigheten]. Folkhälsan i Sverige. Årsrapport 2014 [Public Health in Sweden. Annual Report 2014.], https://www.folkhalsomyndigheten.se/contentassets/30d592b0c7834256bd893e1ba0 d56b6c/folkhalsan-i-sverige-arsrapport-2014.pdf (accessed 8 September 2017)

[8] Pencheon D, Guest C, Meltzer D, et al. Oxford handbook of public health practice. Oxford: Oxford University Press, 2001.

[9] Weinehall L, Hellsten G, Boman K, et al. Prevention of cardiovascular disease in Sweden: The Norsjo community intervention programme - Motives, methods and intervention components. Scand f Public Health 2001;56: 13-20.

[10] Dal Grande E, Fullerton S and Taylor AW. Reliability of self-reported health risk factors and chronic conditions questions collected using the telephone in South Australia, Australia. BMC Med Res Methodol 2012;12:108.

[11] Zajacova A and Dowd JB. Reliability of self-rated health in US adults. Am F Epidemiol 2011;174:977-983.

[12] Statistics Sweden (SCB). Undersökningar av levnadsförhållanden (ULF/SILC) [Living conditions survey] 1975-2005 , https://www.scb.se/sv_/Vara-tjanster/Bestallamikrodata/Vilka-mikrodata-finns/Undersokningarna-avlevnadsforhallanden-ULFSILC/ (accessed 8 September 2017).

[13] O'Donnell MP. Health promotion in the workplace. New York: Delmar Thomson Learning, 2002.

[14] Ministry of Social Affairs [Socialdepartementet]. Ny företagshälsovård: ny kunskapsförsörjning. 2007. New occupational healthcare: New knowledge provision. 2007, http://www.regeringen.se/49b6a9/contentassets/4622f83 34f154200a5e9ac49e3e8c126/ny-foretagshalsovard---nykunskapsforsorining-sou-200791 (accessed 8 September 2017).

[15] The Swedish Council on Technology Assessment in Health Care [Statens beredning för medicinsk utvärdering (SBU)]. Disease prevention in the heart and vessels through population-based programmes: A systematic literature review [Att förebygga sjukdom i hjärta och kärl genom befolkninginriktade program: en systematisk litteraturstudie].Report no. 134, 1997. Stockholm: SBU.

[16] Blair SN and Collingwood TR. Health promotion for educators: Impact on health behaviors, satisfaction and wellbeing. Am F Public Health 1984;74:147-149.

[17] Glanz K, Rimer BK and Viswanath K. Health behavior and health education. Theory, research, and practice. 4th ed. San Fransisco: Jossey-Bass, 2008.

[18] Hart E and Bond M. Action research and social care. Buckingham: Open University Press, 1995.

[19] Weinehall L, Ohgren B, Persson M, et al. High remaining risk in poorly treated hypertension: The 'rule of halves' still exists. F Hypertens 2002;20:2081-2088.

[20] Sobal J. Physicians' beliefs in 25 health promoting behaviors. Am f Public Health 1985;75:1427-1428.

[21] Nordin S, Millqvist E, Löwhagen O, et al. The chemical sensitivity scale: Psychometric properties and comparison with the noise sensitivity scale. F Environ Psychol 2003;23:359-367.

[22] Piccinelli MTE, Bortolomasi M, Piasere O, et al. Efficacy of the alcohol use disorders identification test as a screening tool for hazardous alcohol intake and related disorders in primary care: A validity study. BMF 1997;314:420-424.

[23] Eikelenboom N, Smeele I, Faber M, et al.Validation of SelfManagement Screening (SeMaS), a tool to facilitate personalised counselling and support of patients with chronic diseases. BMC Fam Pract 2015;16:165.

[24] Wallston KA, Wallston BS and DeVellis R. Development of the Multidimensional Health Locus of Control (MHLC) Scales. Health Educ Monogr 1978;6:160-170.
[25] Salen BA, Spangfort EV, Nygren AL, et al. The Disability Rating Index: An instrument for the assessment of disability in clinical settings. F Clin Epidemiol 1994;47:1423-1435.

[26] Terluin B, van Marwijk HW, Ader HJ, et al. The FourDimensional Symptom Questionnaire (4DSQ): A validation study of a multidimensional self-report questionnaire to assess distress, depression, anxiety and somatization. $B M C$ Psychiatry 2006;6:34

[27] Rademakers JNJ, van der Hoek L, Heijmans M, et al. Measuring patient activation in the Netherlands: Translation and validation of the American short form Patient Activation Measure (PAM13). BMC Public Health 2012;12:577.

[28] Mayfield D, McLeod G and Hall P. The CAGE questionnaire. Validation of a new alcoholism screening test. $A m \mathcal{F}$ Psychiatry 1974;131:1121-1123.

[29] Magruder-Habib K, Harris KE and Fraker GG. Validation of the Veterans Alcoholism Screening Test. F Stud Alcohol Drugs 1982;43:910-926.

[30] Fulkerson JA, Lytle L, Story M, et al. Development and validation of a screening instrument to assess the types and quality of foods served at home meals. Int $\mathcal{f}$ Behav Nutr Phys Act 2012;9:10

[31] Yaroch AL, Tooze J, Thompson FE, et al. Evaluation of three short dietary instruments to assess fruit and vegetable intake: The National Cancer Institute's Food Attitudes and Behaviors (FAB) Survey. 7 Acad Nutr Diet 2012;112:1570-1577.

[32] Becker W. Vi äter nyttigare men har blivit tyngre [We eat healthier food but have gained weight]. Varr Föda [Our Diet] 1999;51:3-7.

[33] Becker W. Svenskarna äter nyttigare - allt flera väljer grönt. The Swedes eat healthier food - more people choose green. Vär Föda [Our Diet] 1999;51:24-27.

[34] Sox HC. Preventive health service in adults. $N$ Engl f Med 1994;330:1589-1595.

[35] Weinehall L. Partnership for health. On the role of primary health care in a community intervention programme. 1997, https://www.diva-portal.org/smash/get/diva2:147205/ FULLTEXT02.pdf (accessed 8 September 2017).

[36] Shepard RJ. Exercise as cardiovascular therapy. Clinical Cardiology New Frontiers 1999;99:963-972.

[37] Nordic Nutrition Recommendations. Scand $\mathcal{F}$ Nutr/Näringsforskning 1996;40:16-165.

[38] Johansson L, Thelle DS, Solvoll K, et al. Healthy dietary habits in relation to social determinants and lifestyle factors. Br F Nutr 1999;81:211-220.

[39] Mensink RP and Katan MB. Effect of a diet enriched with monounsaturated or polyunsaturated fatty acids on levels of low-density and high-density lipoprotein cholesterol in healthy women and men. N Engl f Med 1989;17;321:436441.

[40] Björck I, Granfeldt Y, Liljeberg H, et al. Food properties affecting the digestion and absorption of carbohydrates. $\mathrm{Am}$ f Clin Nutr 1994;59:699-705.

[41] Jenkins DJ, Wolever TM, Vuksan V, et al. Nibbling versus gorging: Metabolic advantages of increased meal frequency. N Engl f Med 1989;321:929-934.

[42] Jenkins DJ, Ocana A, Jenkins AL, et al. Metabolic advantages of spreading the nutrient load: Effects of increased meals frequency in non-insulin-dependent diabetes. $A m \mathcal{F}$ Clin Nutr 1992;55:461-467.

[43] Bergman H, Källmén H, Rydberg U, et al. Audit. The alcohol Use Disorder Identification Test. Karolinska Institutet 1994, http://www.sjuharad.se/bdh_filearea/Missbruksprojektet/AUDIT_svensk_manual_1_0.pdf (accessed 8 September 2017).

[44] Singer E, Frankell MR and Glassman MB. The effect of interviewer characteristics and expectations on response. Public Opin Q 1983;47:68-83. 
[45] Field A. Discovering statistics using IBM SPSS statistics: and sex and drugs and rock ' $n$ ' roll. $4^{\text {th }}$ ed. London: Sage, 2013.

[46] Hartman J. Vetenskapligt tänkande: Från kunskapsteori till metodteori [Scientific thinking: From knowledge theory to method theory]. Lund: Studentlitteratur, 2004

[47] Wilde Larsson B and Larsson G. Development of a short form of the Quality from the Patient's Perspective (QPP) questionnaire. F Clin Nurs 2002;11:681-687.

[48] Sørensen J, Davidsen M, Gudex C, et al. Danish EQ-5D population norms. Scand f Public Health 2009;37: 467-474.

[49] Glasberg A-L, Eriksson S, Dahlqvist V, et al. Development and initial validation of the Stress of Conscience Questionnaire. Nurs Ethics 2006;13:633-648.

[50] Nilsson J, Johansson E, Egmar AC, et al. Development and validation of a new tool measuring nurses' self-reported professional competence - The nurse professional competence (NPC) Scale. Nurse Educ Today 2014;34:574-580.

[51] The Swedish Council on Technology Assessment in Health Care [Statens beredning för medicinsk utvärdering (SBU)]. Utvärdering av metoder $i$ hälso- och sjukvården [Evaluation of methods in health care systems]. Falköping: Erlanders Sverige AB, 2013.

[52] Singer E, Frankel MR and Glassman MB. The effect of interviewer characteristics and expectations on response. Public Opin Q 1983;47:68-83.

[53] Betydelsen av patientcentrering och hälsofrämjande [Importance of patient centering and health promotion], http://riddargatan 1 .se/audit/patientcentrering_och_halsoframjande (2015, accessed 8 September 2017).

[54] Thomsson $\mathrm{H}$ and Menckel E. Vad är hälsobefrämjande arbetsplatser? - ett svenskt perspektiv [What are health promotion work places? - A Swedish perspective]. Ljungby: JOMA torroffset, 1997. 